\title{
proposed Amendments to the Constitution and By-Laws
}

The Council of the American Meteorological Society approved the following proposed amendments to the Constitution and By-Laws of the Society and hereby publishes them in accordance with Article VII of the Constitution and Article IX of the By-Laws. The proposed amendments, accompanied by a ballot, will be mailed to each member eligible to vote in October 1968.

Amend Paragraph 1 of Article III of the Constitution to read as follows:

1. The membership of the Society shall consist of:

Honorary Members
Fellows
Professional Members
Associate Members
Corporation Members
Student Members

Only Fellows and Professional Members are eligible to vote, to hold office and to be members of the Council with such further limitations as may be imposed by this Constitution and the By-Laws. Notwithstanding the preceding sentence, those in the grade of Member on December 31, 1965, who became Associate Members on that date are eligible to vote.

The purpose of this amendment is to rearrange the order of listing the grades of membership and, by the inclusion of the last sentence referring to Associate Members, to eliminate Paragraph 10 of Article III.

Amend Paragraph 5 of Article III of the Constitution to read as follows:

Those eligible as candidates for election to Professional Member shall be persons who hold a degree from an institution of higher learning in meteorology, climatology or a related discipline, and who have served these sciences or their applications in furtherance of the objectives of the Society as set forth in Article II of this Constitution.

The proposed amendment makes no change in the requirement that a Professional Member must hold a degree from an institution of higher learning.

The proposed amendment does change the following portion of Paragraph 5:

“. . . who are contributing to the development of the science or the application of meteorology, climatology or other area of atmospheric science." and substitutes therefor:

“. . . who have served these sciences or their applications in furtherance of the objectives of the Society as set forth in Article II of this Constitution."

The objectives of the Society are set forth in Article II of the Constitution which reads as follows:

"The objects of this Society are: The development and dissemination of knowledge of meteorology in all its phases and applications, and the advancement of its professional ideals."

Strike out Paragraph 10 of Article III of the Constitution regarding Associate Members.

The exception in the present paragraph is provided for in the proposed amendment to Paragraph 1 of Article 3 of the Constitution.

Amend the title of Article IV of the Constitution to read:

Article IV. Elective Offices

The purpose is to make the title plural instead of singular.

Amend Paragraph 1 of Article $V$ of the Constitution to read:

1. The elective officers, the last two ex-presidents and a total of fifteen other members, shall constitute a Council which shall have general charge of the affairs of the Society. The President shall be Chairman of the Council and the President-Elect shall be ViceChairman.

The present Paragraph 1 of Article $\mathrm{V}$ contains a phrase reading "elected in a manner specified in Article VI." The reference to Article VI is omitted as inapplicable in this proposed amendment because Paragraph 2 of Article $\mathrm{V}$ now provides that one member of the Council shall be elected by the Council and that the other four members shall be elected in accordance with the procedure set forth in Article VI of the Constitution and Article $\mathrm{V}$ of the By-Laws.

Amend Article $V$ of the Constitution by adding thereto the following:

6. The Council may appoint such other officers as may be required.

This provision is now included in Paragraph 7 of Article VI of the Constitution. It was considered preferable to include it under Article V concerning the Council's responsibilities. 
Amend Article VI of the Constitution so that it will read as follows:

\section{Article VI. Election of Officers and Councilors}

1. The election of elective Officers and Councilors by members eligible to vote, shall be by mail ballot.

2. At least ninety days prior to the Annual Meeting, the Secretary-Treasurer shall mail to each member eligible to vote a ballot containing the names of the nominees for elective office and councilor. The ballot may contain any questions designated by the Council or by a petition signed by at least fifty members who were eligible to vote on the preceding May 1.

3. The ballots shall be cast by mail and to be counted must be received by the Secretary-Treasurer at the headquarters of the Society at least thirty days prior to the date of the next Annual Meeting. The person receiving the highest number of votes for an office, shall be deemed and declared to be elected to such office; and if two or more are to be elected to positions on the Council, the several persons, to the number to be chosen to such positions, receiving the highest number of votes shall be deemed and declared to be elected. In the event of a tie vote the selection shall be made by the retiring Council.

4. Any elective Officer or Councilor may be removed from office for due cause by a vote of at least twothirds of the entire Council.

5. The term of office of the elective Officers and Councilors shall commence at the adjournment of the Annual Meeting at which their election is announced and shall end when their successors take office.

6 . The Council may lay down additional rules governing elections not inconsistent with the Constitution and By-Laws.

The purpose of the above amendments is to clarify the election procedures. It makes no substantial changes in the present Constitutional provisions. Paragraph 7, regarding replacements for vacant offices in the present Constitution is omitted as the proposed amendment to Paragraph 6 of Article $\mathrm{V}$ of the Constitution gives the Council this authority.

Amend Article VII of the Constitution so that it will read as follows:

\section{Article VII. Amendments}

1. No part of the Constitution or By-Laws shall be amended or annulled except by mail ballot in the following manner: A proposed amendment shall be approved by the Council or submitted to the Secretary-Treasurer in a petition signed by at least fifty members eligible to vote on the preceding May 1. The proposed amendment with the reasons therefor, shall be published in the official organ of the Society at least ninety days before ballots for the amendment are mailed.
2. A proposed amendment, accompanied by a ballot, shall be mailed by the Secretary-Treasurer to each member eligible to vote at least sixty days prior to the date the ballots are to be counted. The ballots to be counted must be received by the Secretary-Treasurer not later than sixty days after they are mailed.

3. The adoption of a proposed amendment shall require the affirmative votes of at least two-thirds of all members voting.

The purpose is to clarify the amendment process and to make it possible to delete Article IX from the ByLaws, the latter being the same as the Article VII in the present Constitution.

Amend Article II of the By-Laws to read as follows:

Article II. Meetings

1. There shall be an Annual Meeting, between the 25 th of December and the 31st of January next following, of the members of the Society at a time and place designated by the Council. Notice of the time and place of the Annual Meeting shall be given by the Secretary-Treasurer not less than sixty days before the date on which the Annual Meeting is held. Other meetings of members shall be held at a time and place designated by the Council and the Secretary-Treasurer shall give notice of the meeting not less than thirty days before the date on which the meeting is held.

2. The rules contained in "Robert's Rules of Order Revised" shall govern the meetings of the Society unless inconsistent with the Constitution, By-Laws or any standing rules of the Society. A quorum for the transaction of business at a meeting shall be at least fifty members present who are eligible to vote. The affirmative vote of a majority of the members present who are eligible to vote shall be required for the resolution of any question. The Council may make other rules for meetings not inconsistent with the Constitution or By-Laws. Business not set forth in the notice of the meeting shall not be transacted if five members eligible to vote object.

3. Local chapters or other bodies of the Society may be organized with the consent of the Council, and the Council shall promulgate rules governing their activities. The Council may withdraw its consent for good cause.

4. The fiscal year of the Society shall conform to the calendar year.

5. If the Council, at its first meeting after a meeting of the members of the Society, determines that any resolution adopted by the members at such meeting affects the fundamental rights of the membership, then such resolution shall be submitted immediately by mail ballot to all members eligible to vote. Approval shall require the affirmative vote of a majority of those voting. The ballots, to be counted, shall be received by the Secretary-Treasurer within thirty days of the date mailed. 
Paragraphs 1 through 4 clarify the procedure to be followed at meetings of the members of the Society. Paragraph 5 gives the membership an opportunity to approve or disapprove, by mail ballot, any action taken at a meeting of the members which affects the fundamental rights of the membership. As only a small number of the members attend such meetings, this proposed amendment seems desirable.

Amend Paragraph 3 of Article III of the By-Laws to read:

3. Business of the Council may be transacted by mail ballot at the direction of the President. The ballot shall be mailed to each member of the Council and the ballot to be counted, shall be returned to the Secretary-Treasurer not later than thirty days after the date the ballot was mailed. An affirmative vote of not less than two-thirds of the Council shall be required for the resolution of any question by mail ballot. If, on the date the ballots are to be counted, the Secretary-Treasurer has received in writing from five or more Councilors a request, with the reasons therefor, that the vote be postponed, the postponement will take place and the matter at issue shall be submitted to a second vote in accordance with the procedure set forth in the two preceding sentences.

The purpose of the amendment is to clarify the mail ballot procedure.

Amend Paragraph 1, Article $V$ of the By-Laws to read:

1. The Council shall arrange for the nomination of candidates for each elective office and Council position to be filled. The report thereon, together with the written consent of each nominee, shall be submitted by May 1 of each year to the Secretary-Treasurer who shall give the report, not later than the next following July 15, to all members eligible to vote. Nominations also may be made by petition signed by at least twenty-five members eligible to vote on the preceding May 1, provided the petition is received by the Secretary-Treasurer together with the written consent of the nominee, not later than the next following September 1.

Amend Article VIII of the By-Laws, Code of Ethics, to read as follows:

\section{CODE OF ETHICS}

In order that the dignity and honor of the meteorological profession may be upheld, that its sphere of usefulness and its contributions to society may be extended, and that meteorologists may be guided as individuals or in association with other meteorologists, the Council of the American Meteorological Society has adopted the following Code of Ethics and Conduct for compliance by the Society's membership:
A. Relationship with the profession as a whole.

1. The meteorologist will endeavor to keep abreast of scientific and technical developments within the profession, and will constantly strive for improvement;

2. He will endeavor to contribute new knowledge to meteorology by making known to the scientific world results of his significant work or research through the media of technical or scientific publications or meetings.

B. Relationship of the meteorologist with his fellow meteorologists.

1. The meteorologist will not engage in unfair competition with other members of his profession;

a) He will not knowingly solicit another meteorologist's client(s),

b) He will not interpose between another meteorologist and his prospective client while negotiations or project developments are in progress,

c) He will attempt to secure work on the basis of qualification and performance, not on lower fees.

2. He will not discredit his fellow meteorologists;

a) He will not directly or indirectly injure the professional reputation, prospects, or practice of another meteorologist; however, he will present information on unethical, illegal, or unfair practice to the proper authority for action.

b) He will not review the work of another meteorologist for the same client, except with the other's full knowledge or consent, or unless the association of the other meteorolgist has been terminated.

3. He will not take credit knowingly for work done by others; in publications or meetings, he will attempt to give credit where due.

C. Relationship of the meteorologist with his clients and the general public.

1. The meteorologist will base his practice on sound scientific principles applied in a scientific manner;

2. He will not direct his professional activities into practices generally recognized as being detrimental to or incompatible with the general public welfare;

3. He will fully advise his client before undertaking work for compensation as to the probability of success;

4. He will refrain from making exaggerated and unwarranted claims and statements; 
a) Long-range predictions which demonstrate little or no skill over climatology shall be identified as outlooks, experimental predictions, or climatological expectancies, as appropriate,

b) Stated claims for skill and accuracy of predictions must be based on verification by valid statistical techniques,

c) General purpose forecasts will not be represented as being adequate for specific operations which are better served by specialized forecasts.
5. He will not use or display the official seal of the American Meteorological Society unless duly authorized by the Society.

6. The meteorologist, regardless of organization affiliation, will refer requests for service which are beyond his professional capabilities or his scope of service to those properly qualified.

Amend Article IX of the By-Laws by striking it out, as the amendment of the By-Laws is covered in proposed Article VII of the Constitution.

\section{MacDonald named to university post}

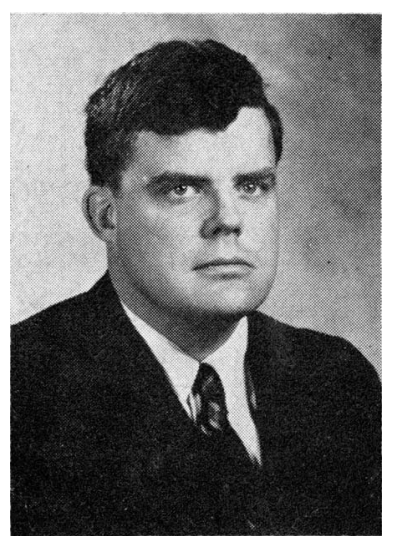

Dr. Gordon J. F. MacDonald, who has been executive vice president of the Institute for Defense Analyses, Arlington, Va., since June 1966, was recently appointed vice chancellor for research and graduate affairs, University of California, Santa Barbara. Dr. MacDonald was also professor of geophysics (1958- ), associate director of the Institute of Geophysics and Planetary Physics $(1960-\quad)$, and director of the Atmospheric Research Laboratory (1960- ), University of California at Los Angeles. In 1960 he was also named consultant to the $\mathrm{Na}$ tional Aeronautics and Space Administration. Between earning his academic degrees at Harvard University and going to UCLA, Dr. MacDonald was assistant professor and then associate professor of geophysics at Massachusetts Institute of Technology.

A member of the National Academy of Sciences, Dr. MacDonald serves on its Atmospheric Sciences Committee as chairman of the Panel on Weather and Climate Modification; on the NAS Space Science Board, he is chairman of three working groups-Planetary Interiors, Surfaces of the Moon and Planets, and Chemistry of the Solar System. In NASA he is a member of the Physics Committee, the Science and Technology Advisory Committee for Manned Space Flight, and the Planetology Subcommittee, where he is chairman of the Working Group on Selenodesy and the Task Group on Surveyor.

Other committee memberships include the President's Science Advisory Committee's Panel on Atmospheric Sciences and consultant to the Space Science Panel and Space Vehicle Panel; the United States Commission 4 (on URSI); the AAAS Committee on Public Understanding of Science; and the AIAA Technical Committee on Astrodynamics.

Among his many publications is Rotation of the Earth, a Geophysical Discussion (Monograph in Applied Mathematics and Mechanics, Cambridge University Press, 1960, coauthored with W. H. Munk), which was awarded the American Academy of Arts and Sciences' Monograph Prize in Physical and Biological Sciences in 1959. He is co-editor of the Journal of the Atmospheric Sciences (AMS), editor of Review of Geophysics (AGU), and associate editor of Proceedings of the National Academy of Sciences, and of Space Science Reviews.

In addition to the National Academy of Sciences, Dr. MacDonald holds membership in the American Academy of Arts and Sciences, American Association for the Advancement of Science, American Astronomical Society, American Geophysical Union, American Mathematical Society, American Meteorological Society, American Mineralogical Society, American Philosophical Society, Geochemical Society of America, Geological Society of America, Royal Astronomical Society, Seismological Society of America, and the Society for Industrial and Applied Mathemaitcs.

\section{Engineering and science building at NYU}

The New York University School of Engineering and Science is building a $\$ 10.5$ million educational and research center to provide full laboratory and office facilities plus "growing room" for its departments of chemical engineering, industrial engineering and operations research, metallurgy and materials sciences, and meteorology and oceanography. The new center will furnish $150,000 \mathrm{sq} \mathrm{ft}$ of space to accommodate the 300 faculty, staff, and graduate students of these four departments now scattered among 17 buildings on and off campus.

"Technology II," as the building is tentatively named, is being built of 11-ton blocks of pre-cast concrete, which form a self-supporting, finished exterior as the building goes up. Even when less than half finished, the $\mathrm{H}$-shaped complex designed by award-winning architect Marcel Breuer, already dominated NYU's University Heights campus in the Bronx. The completed structure will consist of an eight-story laboratory and office wing and a three-story classroom wing connected by a central elevator and service tower. A third section, beneath a raised, open plaza, will be connected with the existing Engineering and Science Library to quadruple library space. The complex will be completely air conditioned. It is scheduled to be finished in the fall of 1969 .

Department of Meteorology and Oceanography facilities planned for the laboratory and office wing include a rooftop weather station and laboratories for weather analysis, atmospheric physics, computing, optics, hydrodynamics, and oceanographic analysis. This department has full educational and research programs and is one of six departments cooperating in an interdisciplinary graduate program in ocean engineering.

(More news and notes on page 410) 


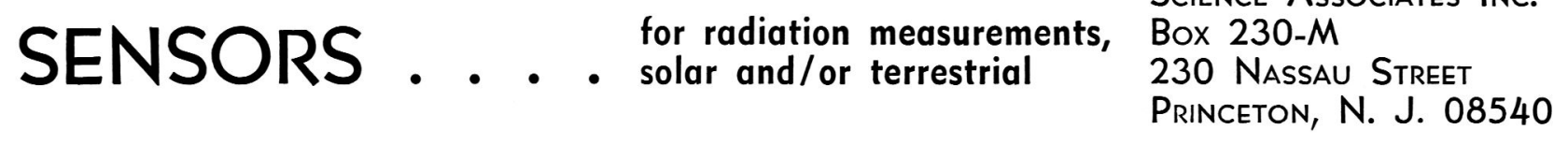 \\ Science Associates Inc.}

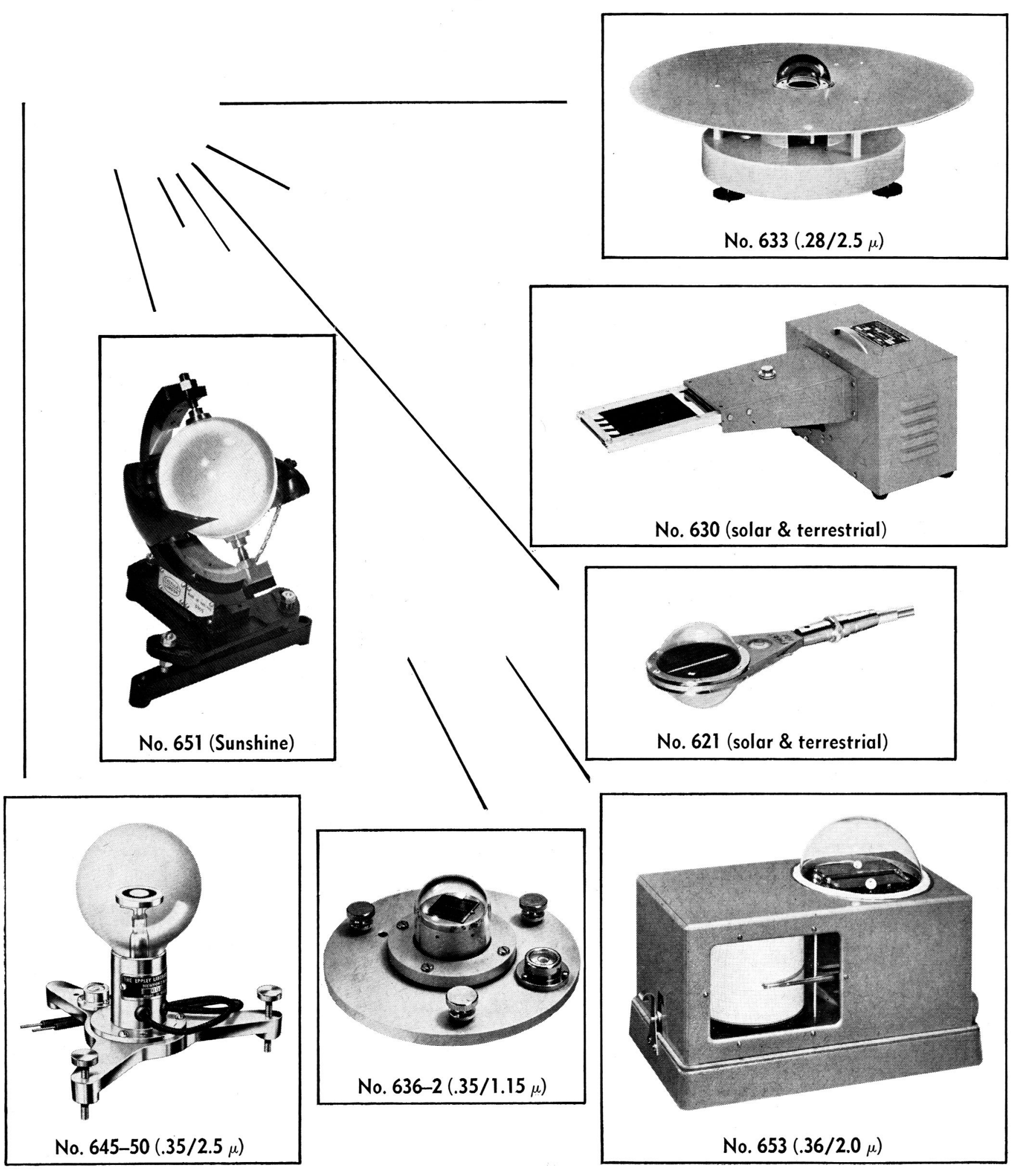

Bulletin American Meteorological Society 